\title{
Article \\ A Low Level of NaCl Stimulates Plant Growth by Improving Carbon and Sulfur Assimilation in Arabidopsis thaliana
}

\author{
Li Hongqiao $^{1}{ }^{\mathbb{D}}$, Akiko Suyama ${ }^{1,2}$, Namiki Mitani-Ueno ${ }^{3}$, Ruediger Hell ${ }^{4} \mathbb{D}$ \\ and Akiko Maruyama-Nakashita ${ }^{1, *(D)}$ \\ 1 Department of Bioscience and Biotechnology, Faculty of Agriculture, Kyushu University, \\ 744, Motooka, Nishi-ku, Fukuoka 819-0395, Japan; li.hongqiao.538@s.kyushu-u.ac.jp (L.H.); \\ aksuyama@nm.beppu-u.ac.jp (A.S.) \\ 2 Department of Food and Fermentation Sciences, Faculty of Food and Nutrition Sciences, Beppu University, \\ 82, Kita-ishigaki, Beppu-shi, Oita 874-8501, Japan \\ 3 Institute of Plant Science and Resources, Okayama University, Chuo 2-20-1, Kurashiki 710-0046, Japan; \\ namiki-m@rib.okayama-u.ac.jp \\ 4 Centre for Organismal Studies, Heidelberg University, Im Neuenheimer Feld 360, \\ 69120 Heidelberg, Germany; ruediger.hell@cos.uni-heidelberg.de \\ * Correspondence: amaru@agr.kyushu-u.ac.jp; Tel.: +81-92-802-4712
}

check for updates

Citation: Hongqiao, L.; Suyama, A.; Mitani-Ueno, N.; Hell, R.;

Maruyama-Nakashita, A. A Low Level of $\mathrm{NaCl}$ Stimulates Plant Growth by Improving Carbon and Sulfur Assimilation in Arabidopsis thaliana. Plants 2021, 10, 2138. https://doi.org/10.3390/plants10102138

Academic Editor: Styliani (Stella) Chorianopoulou

Received: 13 September 2021

Accepted: 4 October 2021

Published: 9 October 2021

Publisher's Note: MDPI stays neutral with regard to jurisdictional claims in published maps and institutional affiliations.

Copyright: (c) 2021 by the authors. Licensee MDPI, Basel, Switzerland. This article is an open access article distributed under the terms and conditions of the Creative Commons Attribution (CC BY) license (https:// creativecommons.org/licenses/by/ $4.0 /)$.

\begin{abstract}
High-salinity stress represses plant growth by inhibiting various metabolic processes. In contrast to the well-studied mechanisms mediating tolerance to high levels of salt, the effects of low levels of salts have not been well studied. In this study, we examined the growth of Arabidopsis thaliana plants under different $\mathrm{NaCl}$ concentrations. Interestingly, both shoot and root biomass increased in the presence of $5 \mathrm{mM} \mathrm{NaCl}$, whereas more than $10 \mathrm{mM} \mathrm{NaCl}$ decreased plant biomass. To clarify the biological mechanism by which a low level of $\mathrm{NaCl}$ stimulated plant growth, we analyzed element accumulation in plants grown under different $\mathrm{NaCl}$ concentrations. In addition to the $\mathrm{Na}$ and $\mathrm{Cl}$ contents, $\mathrm{C}, \mathrm{S}, \mathrm{Zn}$, and $\mathrm{Cu}$ contents were increased under $5 \mathrm{mM} \mathrm{NaCl}$ in shoots; this was not observed at higher $\mathrm{NaCl}$ concentrations. Adverse effects of high salinity, such as decreased levels of nitrate, phosphate, sulfate, and some cations, did not occur in the presence of $5 \mathrm{mM} \mathrm{NaCl}$. An increase in $\mathrm{C}$ was possibly attributed to increased photosynthesis supported by $\mathrm{Cl}, \mathrm{Zn}$, and $\mathrm{Cu}$, which also increased in shoots after $\mathrm{NaCl}$ application. Salt stress-responsive gene expression was enhanced under $20 \mathrm{mM} \mathrm{NaCl}$ but not at lower doses. Among the $\mathrm{S}$ metabolites analyzed, cysteine (Cys) was increased by $5 \mathrm{mM} \mathrm{NaCl}$, suggesting that $\mathrm{S}$ assimilation was promoted by this dose of $\mathrm{NaCl}$. These results indicate the usefulness of $\mathrm{NaCl}$ for plant growth stimulation.
\end{abstract}

Keywords: sodium; chloride; carbon; sulfur; plant growth

\section{Introduction}

High salinity has become an important issue in agricultural production in many regions of the world and has led to a drastic reduction in plant growth and biomass production of crops [1-3]. Under high salinity, which usually corresponds to a high concentration of $\mathrm{NaCl}$ in the soil environment, the cellular concentrations of sodium $\left(\mathrm{Na}^{+}\right)$ and chloride $\left(\mathrm{Cl}^{-}\right)$ions increase. This causes osmotic stress and leads to toxic effects, including a decrease in the level of other cations, such as $\mathrm{K}^{+}$, production of reactive oxygen species (ROS), and inhibition of membrane integrity, protein synthesis, cellular metabolism, photosynthesis, and water and nutrient acquisition $[2,4]$. To cope with these toxic effects of $\mathrm{NaCl}$, plants have evolved the salt overly sensitive (SOS) pathway, which regulates ion homeostasis under salinity stress $[2,4,5]$.

Because of its severe impact on agricultural production, research pertaining to understanding the effects of $\mathrm{NaCl}$ is mainly focused on analyzing the effects of high doses (more than $50 \mathrm{mM}$ ), while the potential beneficial effects of low doses are relatively less 
investigated. Sodium is a beneficial element for plants [6,7]. Na functions as an indispensable element for most $\mathrm{C}_{4}$ species, as $\mathrm{Na}^{+}$is required for pyruvate import to the chloroplast, which supports the carbon fixation process in $\mathrm{C}_{4}$ photosynthesis $[7,8]$. Nitrogen uptake and assimilation, as well as the activity of photosystem II, require $\mathrm{Na}$ in $\mathrm{C}_{4}$ species [7]. In addition to $C_{4}$ plants or halophytes, many $C_{3}$ plants have shown growth stimulation upon $\mathrm{Na}$ application [6,7]. Under potassium (K) deficiency, Na can partly substitute the functions of K, e.g., by serving as an osmoticum, a counter ion for anion in long-distance transport, and an enzymatic activator $[7,9,10]$. Growth stimulation by a relatively low level of $\mathrm{NaCl}$ (less than $20 \mathrm{mM}$ ) has also been reported for Chenopodiaceae, sugar beet, red beet, tomato, potato, sunflower, etc., even under an adequate supply of $\mathrm{K}[7,11]$. Improvement of water use efficiency was observed in Chrysanthemum with $50 \mathrm{mM} \mathrm{NaCl}$ [12]. However, growth promotion by a low level of $\mathrm{NaCl}$ largely depends on the plant species and on growth conditions [7].

Chlorine is an essential nutrient for plants and is involved in osmoregulation and turgor maintenance [6]. In the chloroplast, $\mathrm{Cl}^{-}$functions as an indispensable component of photosystem II (PSII) by stabilizing the water de-composition/oxygen liberation system $[13,14]$. In addition, $\mathrm{Cl}^{-}$regulates the activities of some enzymes, such as asparagine synthetase, vacuolar proton pump ATPase, and amylase [13,15]. The regulation of $\mathrm{Cl}^{-}$ homeostasis is critical in stomatal guard cells and growing pollen tubes [16]. Various kinds of crops respond significantly to $\mathrm{Cl}^{-}$fertilizers $[11,17,18]$, although most studies have not clarified the effects of accompanying cations (such as $\mathrm{Na}^{+}$) on the increased agricultural yield [14]. Low concentrations of $\mathrm{Cl}^{-}(1$ to $5 \mathrm{mM})$ promote plant growth by increasing leaf cell size, reducing transpiration, and improving water-use efficiency in tobacco and tomato plants $[19,20]$.

The relationship between sulfur (S) metabolism and salt has also been mainly investigated with respect to the contributions of $S$ assimilation and S-containing compounds to salt stress. Plants take up $\mathrm{S}$ mostly as sulfate through the activity of sulfate transporters (SULTR). Intracellular sulfate is activated to adenosine $5^{\prime}$-phosphosulfate (APS) by ATP sulfurylase and then reduced to sulfide by the actions of APS reductase (APR) and sulfite reductase. Then, sulfide is converted to cysteine (Cys) upon reaction with $O$-acetyl-L-serine, which is catalyzed by $O$-acetyl-L-serine (thiol) lyase [21-23]. The common antioxidant glutathione (GSH) is synthesized from Cys via ATP-dependent reactions catalyzed by gamma-glutamylcysteine synthase and GSH synthase. Under salt stress, various plants, including Arabidopsis, induce Cys biosynthesis to prevent oxidative stress caused by high salinity $[24,25]$. Indeed, the overexpression of enzymes involved in Cys and GSH synthesis increases the salt tolerance of plants [26,27]. However, the contribution of $S$ assimilation to growth stimulation caused by low $\mathrm{NaCl}$ concentrations has not been analyzed till date.

Based on this background, we aimed to demonstrate the effect of $\mathrm{NaCl}$ dosage on plant growth, element accumulation, and $\mathrm{S}$ assimilation in the model plant Arabidopsis thaliana. We found that a low level of $\mathrm{NaCl}$ stimulates plant growth. The analysis of elements and $\mathrm{S}$ metabolites suggested that increased $\mathrm{S}$ assimilation and content of some elements could contributed to enhanced plant growth under low levels of $\mathrm{NaCl}$.

\section{Results}

\subsection{Low Concentration of $\mathrm{NaCl}$ Promoted Plant Growth}

Plants were grown for 11 days on agar medium containing $0,5,10,20,40$, or $60 \mathrm{mM}$ $\mathrm{NaCl}$ (Figure 1a). The shoot and root fresh weights under $5 \mathrm{mM} \mathrm{NaCl}$ were significantly higher than those without $\mathrm{NaCl}$ application, whereas root fresh weights decreased in the presence of $20 \mathrm{mM}$ and higher concentrations of $\mathrm{NaCl}$ (Figure $1 \mathrm{~b}$ ). These results indicated that the presence of $5 \mathrm{mM} \mathrm{NaCl}$ positively influenced plant growth on the agar medium, which was in clear contrast with the obvious growth retardation observed in the presence of $20 \mathrm{mM}$ and higher concentrations of $\mathrm{NaCl}$. As we considered appealing the growth stimulation by $5 \mathrm{mM} \mathrm{NaCl}$, we focused on lower doses of $\mathrm{NaCl}$ in the following analysis. 
a

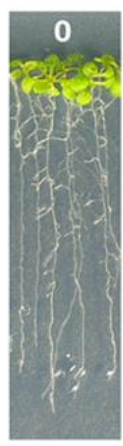

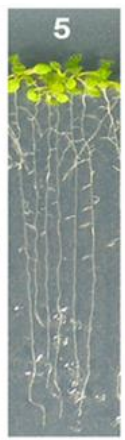
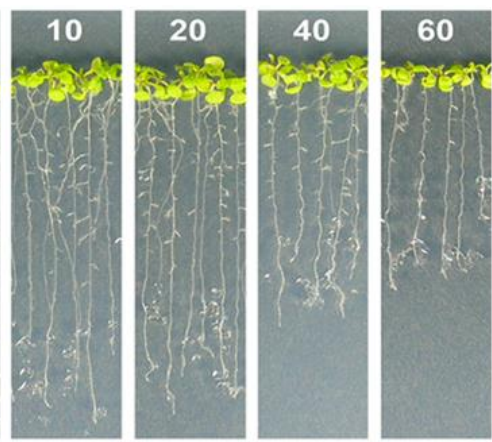

b
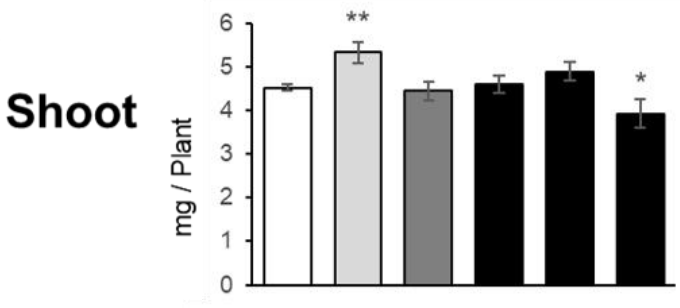

Root

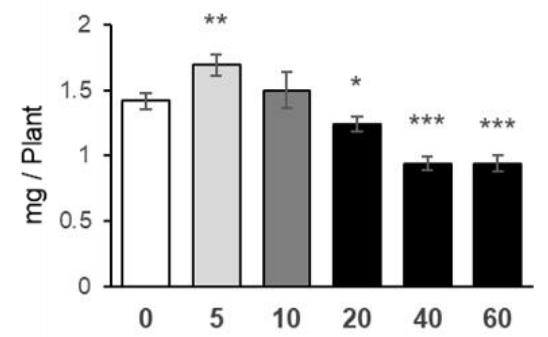

Figure 1. Plant growth under $\mathrm{NaCl}$ treatment. Plants were grown for 11 days on agar medium containing 0, 5, 10, 20, 40 , or $60 \mathrm{mM} \mathrm{NaCl}$. NaCl concentrations are indicated by the number on each photo. After capturing the images of the plants (a), shoots and roots were harvested separately. (b) Fresh weight of shoots (upper) and roots (lower). Bars and error bars represent the mean and standard error $(n=6)$, respectively. Asterisks indicate significant differences between $\mathrm{NaCl}$-treated and non-treated plants as calculated using Student's $t$-test $\left({ }^{*} 0.01 \leq p<0.05,{ }^{* *} 0.001 \leq p<0.01,{ }^{* * *} p<0.001\right)$.

\subsection{Increase in $\mathrm{NaCl}$ Concentration Decreased Nitrate and Sulfate Content, but Their Levels Were Maintained under $5 \mathrm{mM} \mathrm{NaCl}$}

To determine the effects of $\mathrm{NaCl}$ application on the content of chloride $\left(\mathrm{Cl}^{-}\right)$and other anions in plants, we analyzed $\mathrm{Cl}^{-}$, nitrate $\left(\mathrm{NO}_{3}{ }^{-}\right)$, phosphate $\left(\mathrm{PO}_{4}{ }^{3-}\right)$, and sulfate $\left(\mathrm{SO}_{4}{ }^{2-}\right)$ contents using ion chromatography (Figure 2). The application of $\mathrm{NaCl}$ resulted in a significant increase in $\mathrm{Cl}^{-}$content in both the shoots and the roots of Arabidopsis. $\mathrm{Cl}^{-}$ levels increased in both shoots and roots even under $5 \mathrm{mM} \mathrm{NaCl}$ and further continuously increased with increasing $\mathrm{NaCl}$ concentration. $\mathrm{NO}_{3}{ }^{-}$and $\mathrm{SO}_{4}{ }^{2-}$ contents in shoots and roots were maintained and not affected by $5 \mathrm{mM}$ and $10 \mathrm{mM} \mathrm{NaCl}$; however, the contents of these ion started to decrease in shoots when higher concentrations of $\mathrm{NaCl}$ were added to the growth medium. $\mathrm{NO}_{3}{ }^{-}$and $\mathrm{SO}_{4}{ }^{2-}$ contents in roots and $\mathrm{PO}_{4}{ }^{3-}$ content in both shoots and roots were not influenced by these $\mathrm{NaCl}$ doses.
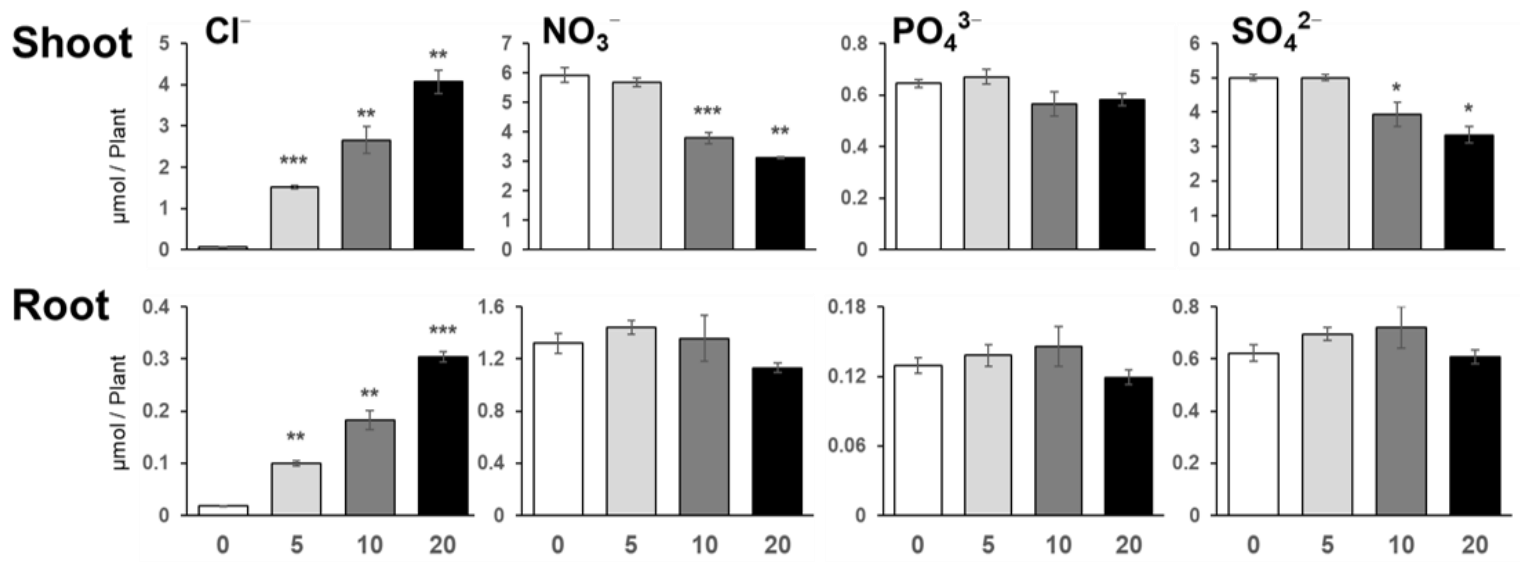

Figure 2. Chloride $\left(\mathrm{Cl}^{-}\right)$, Nitrate $\left(\mathrm{NO}_{3}{ }^{-}\right)$, Phosphate $\left(\mathrm{PO}_{4}{ }^{3-}\right)$, and Sulfate $\left(\mathrm{SO}_{4}{ }^{2-}\right)$ contents in plants under $\mathrm{NaCl}$ treatment. $\mathrm{Cl}^{-}, \mathrm{NO}_{3}{ }^{-}, \mathrm{PO}_{4}{ }^{3-}$, and $\mathrm{SO}_{4}{ }^{2-}$ contents were analyzed in plants grown for 11 days on agar medium containing $0,5,10$, or $20 \mathrm{mM} \mathrm{NaCl}$, using ion chromatography. Bars and error bars represent the mean and standard error $(n=4)$. Asterisks indicate significant differences between the $\mathrm{NaCl}$-treated and the non-treated plants as calculated using Student's $t$-test. $\left({ }^{*} 0.01 \leq p<0.05,{ }^{* *} 0.001 \leq p<0.01,{ }^{* * *} p<0.001\right)$. 


\subsection{Effects of $\mathrm{NaCl}$ on Elemental Contents}

To understand how low levels of $\mathrm{NaCl}$ stimulate plant growth, we analyzed the elemental contents in plants grown under 0, 5, 10, and $20 \mathrm{mM} \mathrm{NaCl}$ (Figure 3). Carbon content was significantly increased by $5 \mathrm{mM} \mathrm{NaCl}$ in both shoots and roots but was decreased by 10 and $20 \mathrm{mM} \mathrm{NaCl}$. Nitrogen content in roots was increased by 5 and $10 \mathrm{mM} \mathrm{NaCl}$ but was reduced by $20 \mathrm{mM} \mathrm{NaCl}$. In shoots, $5 \mathrm{mM} \mathrm{NaCl}$ did not change the $\mathrm{N}$ content, but a higher $\mathrm{NaCl}$ concentration significantly reduced it. These findings may point to enhanced biomass production with respect to $\mathrm{C}$ and $\mathrm{N}$ assimilation at low $\mathrm{NaCl}$ concentrations.
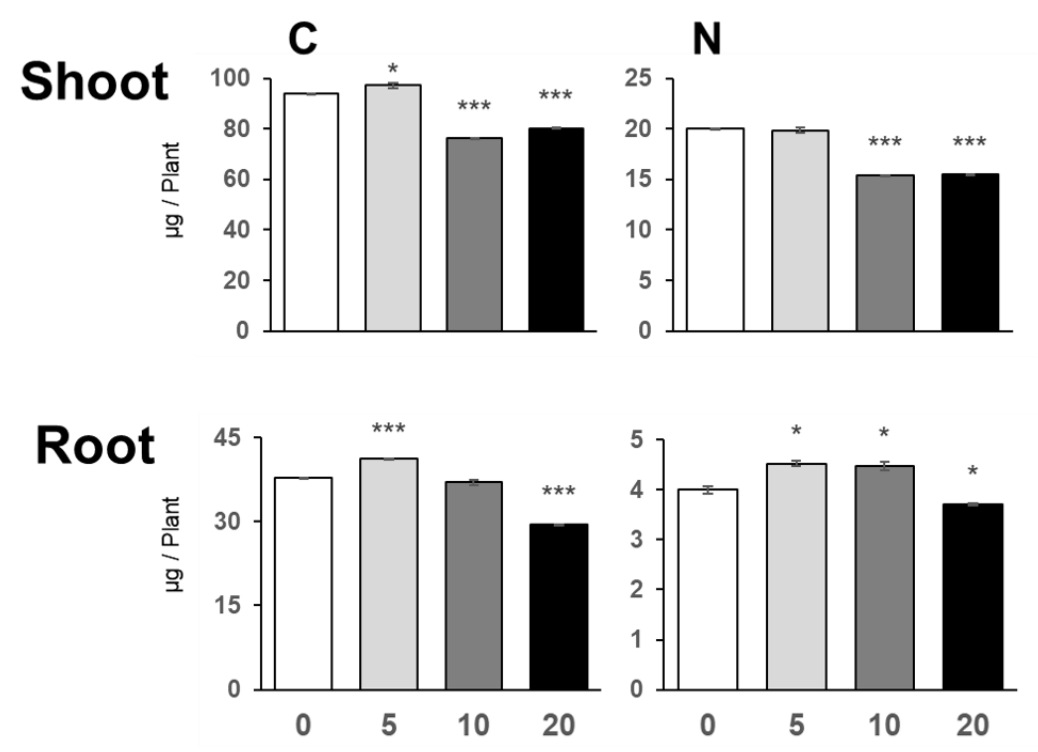

Figure 3. Carbon and Nitrogen contents in plants under $\mathrm{NaCl}$ treatment. $\mathrm{C}$ and $\mathrm{N}$ contents in plants grown for 11 days on agar medium containing $0,5,10$, or $20 \mathrm{mM} \mathrm{NaCl}$ were analyzed with an elemental analyzer. Bars and error bars represent the mean and standard error $(n=3)$. Asterisks indicate significant differences between the $\mathrm{NaCl}$-treated and the non-treated plants as calculated using Student's $t$-test ${ }^{*} 0.01 \leq p<0.05,{ }^{* *} 0.001 \leq p<0.01,{ }^{* * *} p<0.001$ ).

In addition to total $\mathrm{C}$ and $\mathrm{N}$, we analyzed the content of essential elements, viz., $\mathrm{P}, \mathrm{S}, \mathrm{K}$, $\mathrm{Mg}, \mathrm{Ca}, \mathrm{Mn}, \mathrm{Fe}, \mathrm{Zn}, \mathrm{Cu}$, and $\mathrm{Mo}$, along with that of $\mathrm{Na}$, in $\mathrm{NaCl}$-treated plants (Figure 4). $\mathrm{Na}$ content increased with increasing $\mathrm{NaCl}$ concentration and was consistently higher in roots than in shoots. In addition to $\mathrm{Na}, 5 \mathrm{mM} \mathrm{NaCl}$ in the growth medium increased $\mathrm{S}$, $\mathrm{Zn}$, and $\mathrm{Cu}$ contents in shoots, and $\mathrm{P}, \mathrm{K}, \mathrm{Mg}, \mathrm{Ca}$, and $\mathrm{Cu}$ contents in roots. In contrast, the presence of 10 and $20 \mathrm{mM} \mathrm{NaCl}$ resulted in a decrease in most of the elements, including $\mathrm{S}, \mathrm{K}, \mathrm{Mg}, \mathrm{Ca}, \mathrm{Mn}, \mathrm{Cu}$, and $\mathrm{Mo}$, in shoots. In roots, the presence of $10 \mathrm{mM} \mathrm{NaCl}$ led to an increase in the levels of some elements, such as $\mathrm{P}, \mathrm{K}, \mathrm{Mg}, \mathrm{Ca}, \mathrm{Mn}, \mathrm{Zn}$, and $\mathrm{Cu}$, but $20 \mathrm{mM} \mathrm{NaCl}$ decreased most of the elements except for $\mathrm{Mn}, \mathrm{Zn}$, and $\mathrm{Cu}$. Mo content in the roots was slightly increased under $20 \mathrm{mM} \mathrm{NaCl}$. These results indicated that $5 \mathrm{mM} \mathrm{NaCl}$ increased the content of various elements.

\subsection{Low Level of $\mathrm{NaCl}$ Increased Cys Content in Shoots}

Plant growth and elemental analysis showed that low-NaCl-dependent plant growth stimulation correlated with increased C, S, Zn, and Cu levels in shoots. Increased C levels may be attributed to photosynthesis, as supported by the increased $\mathrm{Cl}, \mathrm{Mn}, \mathrm{Cu}$, and $\mathrm{Mg}$ contents [28]. Here, we focused on the increased S content to demonstrate how it may contribute to increased plant growth and examined the contents of the major $\mathrm{S}$ compounds, namely, Cys and GSH (Figure 5). 


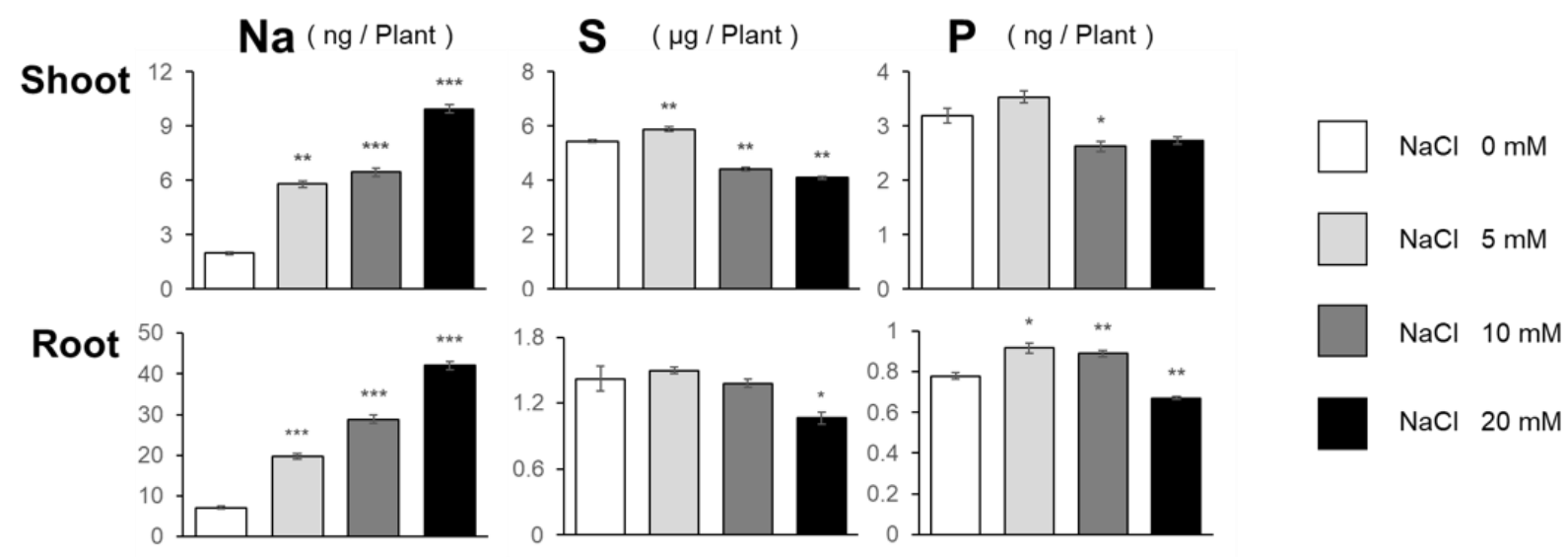

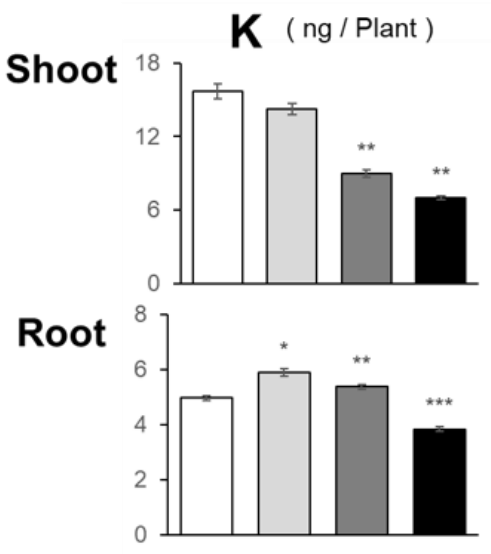

$\mathbf{F e}$ ( pg / Plant )

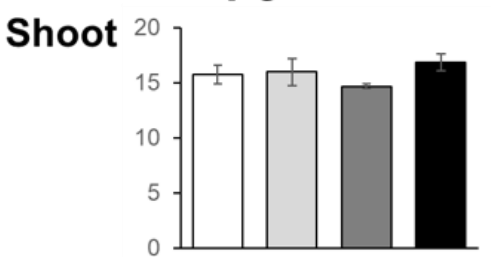

Root

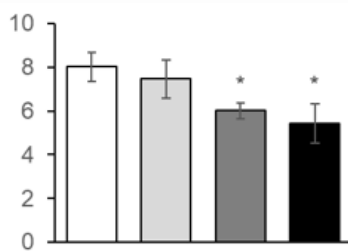

$\mathbf{M g}$ ( ng / Plant )

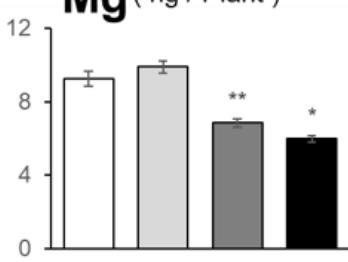

Ca (ng / Plant)
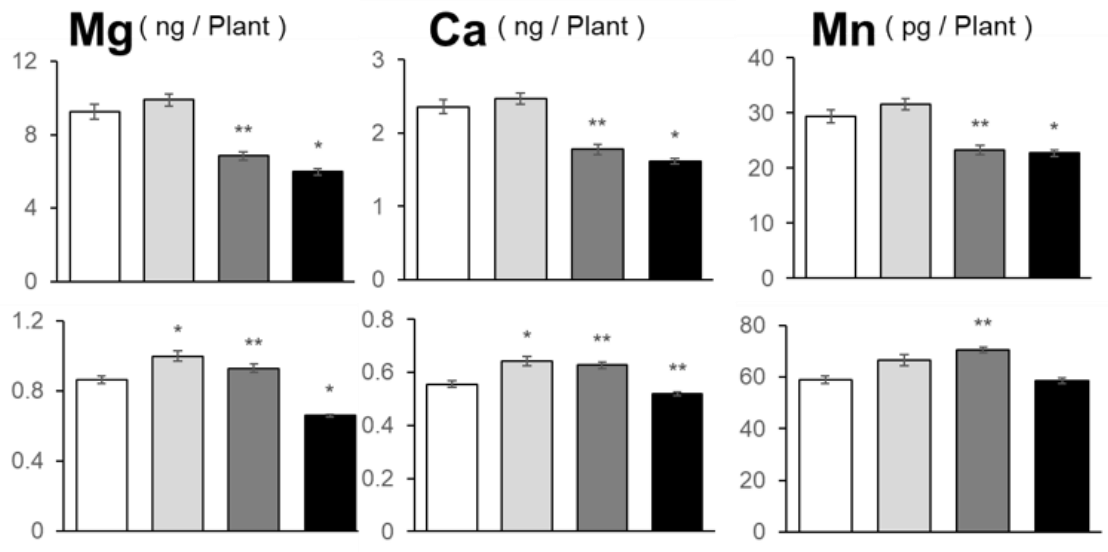

Zn (pg/ Plant)

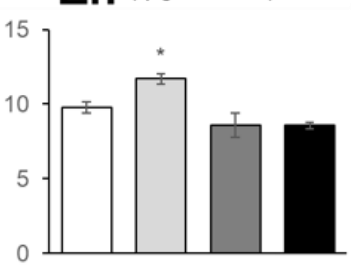

Cu (pg/Plant)

Mo ( pg / Plant )
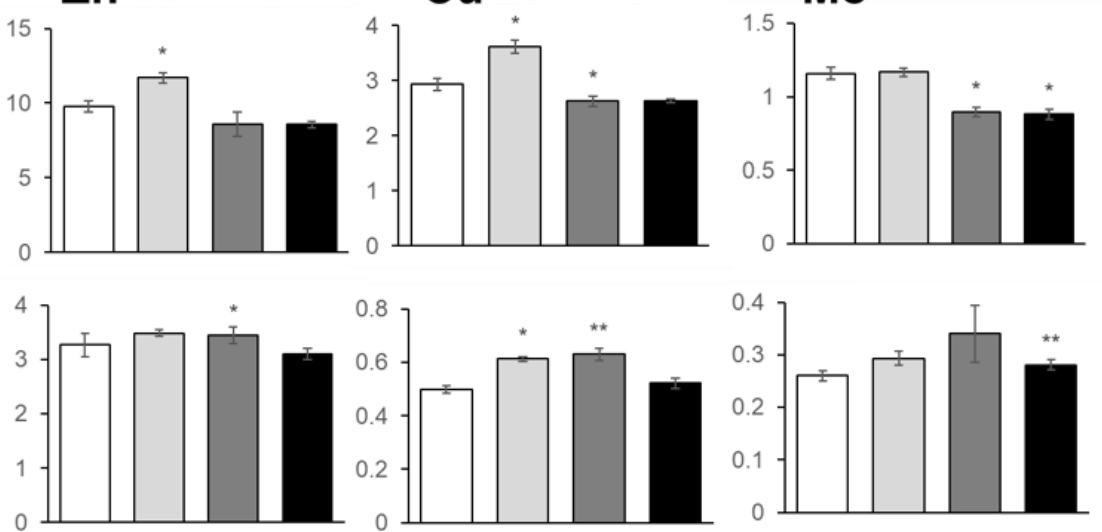

Figure 4. Sodium and essential elements' content in plants under $\mathrm{NaCl}$ treatment. $\mathrm{Na}$, Sulfur, Phosphorus, Potassium, Magnesium, Calcium, Manganese, Iron, Zinc, Copper, and Molybdenum contents in plants grown for 11 days on agar medium containing $0,5,10$, or $20 \mathrm{mM} \mathrm{NaCl}$ were measured using ICP-MS. Bars and error bars represent the mean and standard error $(n=3)$. Asterisks indicate significant differences between the $\mathrm{NaCl}$-treated and the non-treated plants as calculated using Student's $t$-test. $\left({ }^{*} 0.01 \leq p<0.05,{ }^{* *} 0.001 \leq p<0.01,{ }^{* * *} p<0.001\right)$.

Cys content in shoots increased under $5 \mathrm{mM} \mathrm{NaCl}$, and a similar tendency was observed in root Cys content (Figure 5). The application of higher levels of $\mathrm{NaCl}$ did not affect the Cys content in either shoots or roots. GSH content in shoots was reduced in the presence of $20 \mathrm{mM} \mathrm{NaCl}$; however, that in roots was increased by $10 \mathrm{mM} \mathrm{NaCl}$ and was maintained by $5 \mathrm{mM} \mathrm{NaCl}$. 

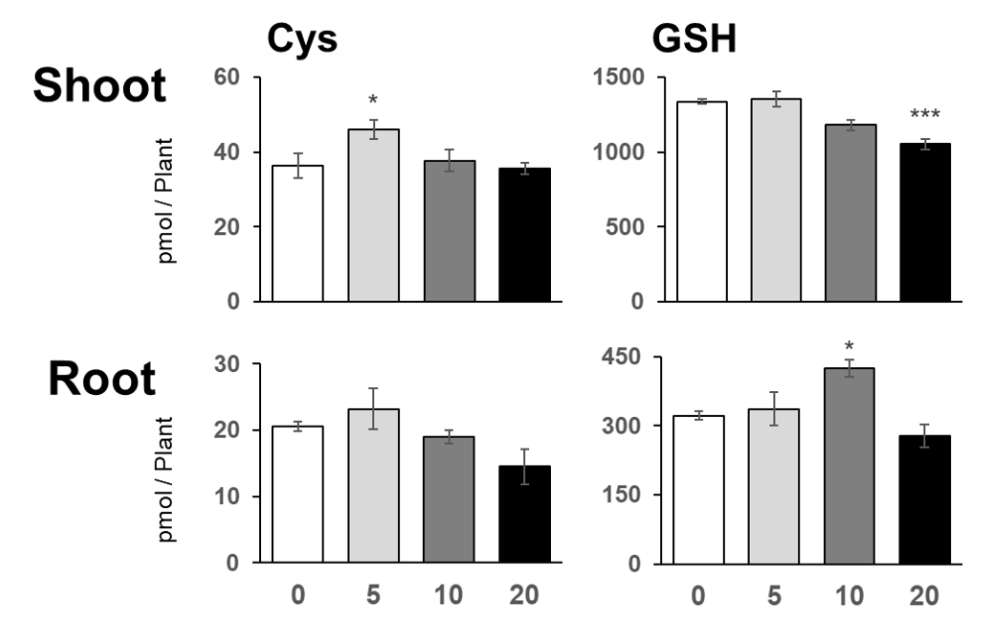

Figure 5. Cysteine (Cys) and Glutathione (GSH) contents in plants under $\mathrm{NaCl}$ treatment. Cys and GSH contents in plants grown for 11 days on agar medium containing $0,5,10$, or $20 \mathrm{mM} \mathrm{NaCl}$ were analyzed using an HPLC fluorescence detector system. Bars and error bars represent the mean and standard error $(n=4)$. Asterisks indicate significant differences between the NaCl-treated and the non-treated plants as calculated using Student's $t$-test $\left({ }^{*} 0.01 \leq p<0.05,{ }^{* *} 0.001 \leq p<0.01\right.$, *** $p<0.001)$.

Since $\mathrm{S}$ and Cys levels were increased by $5 \mathrm{mM} \mathrm{NaCl}$, we analyzed the expression of some $\mathrm{S}$ assimilatory genes, namely, SULTR1;1, SULTR1;2, APR2, and APR3, which are involved in reactions known as key processes in $S$ assimilation [21]. To know whether plants sensed $5 \mathrm{mM} \mathrm{NaCl}$ as salt stress, we also analyzed the expression of the salt stressresponsive genes NHX1 and SLAH1 [2] (Figure 6). As SULTR1;1 expression was too low to be detected, we present the transcript levels of SULTR1;2, APR2, and APR3. The expression of these genes did not increase with these $\mathrm{NaCl}$ dosages (Figure 6). The transcript levels of NHX1 and SLAH1 responded to $20 \mathrm{mM} \mathrm{NaCl}$ but not to 5 and $10 \mathrm{mM} \mathrm{NaCl}$, i.e., $20 \mathrm{mM}$ $\mathrm{NaCl}$ upregulated NHX1 in shoots and downregulated SLAH1 in roots (Figure 6).

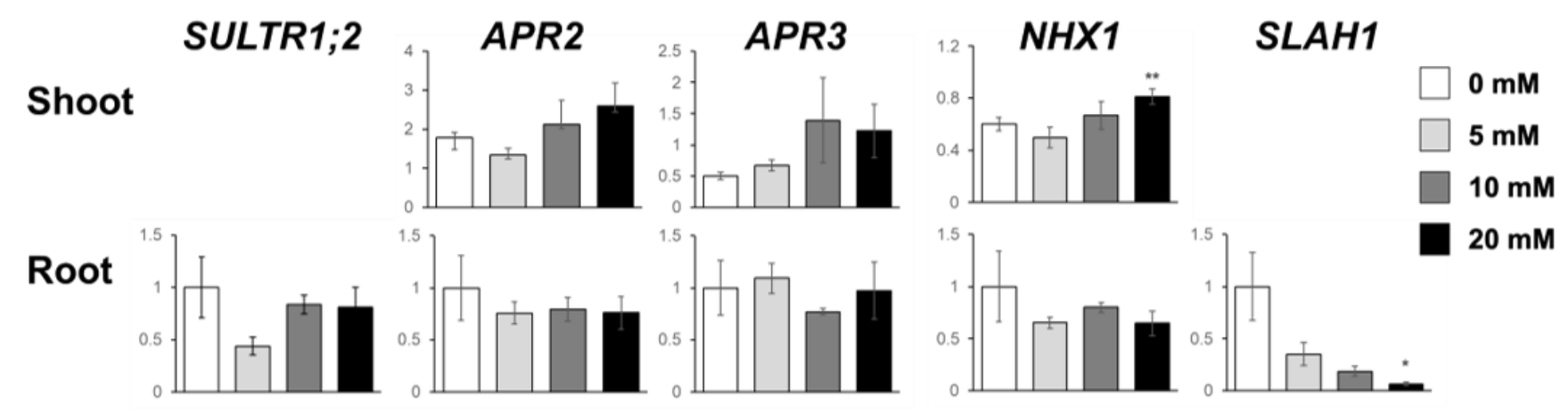

Figure 6. Expressions of $\mathrm{S}$ assimilatory and salt stress-responsive genes in plants under $\mathrm{NaCl}$ treatment. Gene expression of SULTR1;2, APR2, APR3, NHX1, and SLAH1 was analyzed by quantitative RT-PCR. Relative mRNA abundance was determined using the $\triangle \triangle \mathrm{Ct}$ method, and ubiquitin (UBQ2, accession no. J05508) was used as an internal control. Values relative to the roots without $\mathrm{NaCl}$ treatment are presented. Asterisks indicate significant differences between the $\mathrm{NaCl}-$ treated and the non-treated plants as calculated using Student's $t$-test $\left({ }^{*} 0.01 \leq p<0.05,{ }^{* *} 0.001 \leq p<0.01,{ }^{* * *} p<0.001\right)$.

\subsection{Low Levels of $\mathrm{KCl}$ and $\mathrm{NaNO}_{3}$ Stimulated Plant Growth}

To understand whether $\mathrm{Na}^{+}$or $\mathrm{Cl}^{-}$plays any crucial role in the growth stimulation of Arabidopsis, we tested plant growth in the presence of three different salts: $\mathrm{KCl}, \mathrm{NaNO}_{3}$, and $\mathrm{NaCl}$ (Figure 7). Although the effective concentrations were different, both $\mathrm{KCl}(10 \mathrm{mM})$ and $\mathrm{NaNO}_{3}(5 \mathrm{mM})$ increased the fresh weight $(\mathrm{FW})$ of plant shoots, as was observed with $\mathrm{NaCl}$ application. We found that $10 \mathrm{mM} \mathrm{NaNO}_{3}$ decreased the root $\mathrm{FW}$, suggesting that 
this combination of increased $\mathrm{Na}^{+}$and $\mathrm{NO}_{3}{ }^{-}$could be detrimental for plants. These results indicated that both $\mathrm{Na}^{+}$and $\mathrm{Cl}^{-}$in this concentration range could increase plant growth by acting synergistically.

a

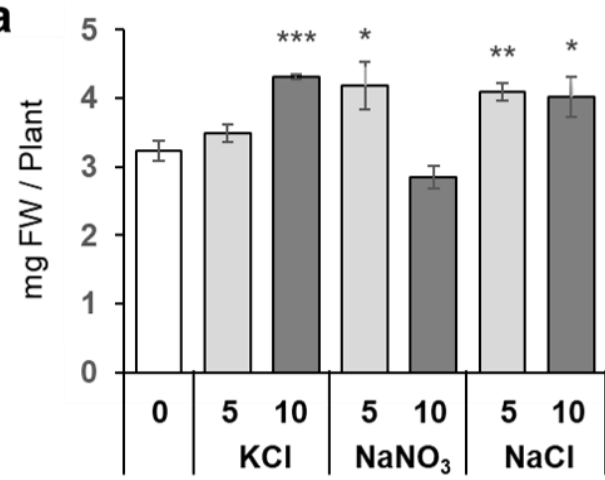

b

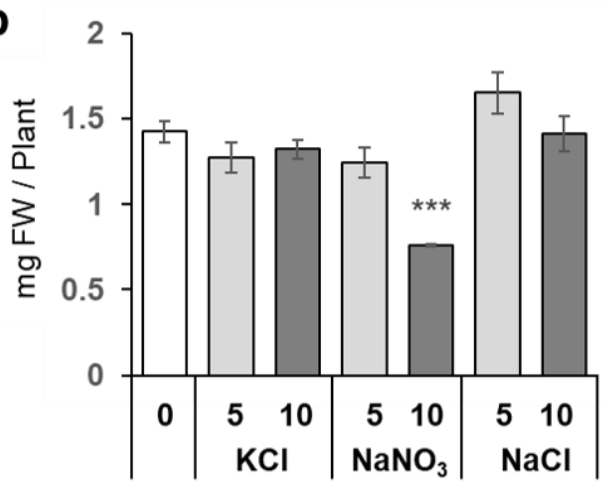

Figure 7. Plant growth in the presence of different salts. Plants were grown for 10 days on agar medium with or without 5 and $10 \mathrm{mM} \mathrm{KCl}, \mathrm{NaNO}_{3}$, and $\mathrm{NaCl}$. Shoot (a) and root (b) tissues were harvested separately, and fresh weights (FW) were recorded. Bars and error bars represent the mean and standard error $(n=4)$. Asterisks indicate significant differences between the salt-treated and the untreated plants as calculated using Student's $t$-test ${ }^{*} 0.01 \leq p<0.05,{ }^{* *} 0.001 \leq p<0.01$, *** $p<0.001$ ).

\section{Discussion}

\subsection{Plant Growth Stimulation by Low-Level NaCl Is Accompanied by Increased C and S Levels}

$\mathrm{NaCl}$ is known to be toxic when it is accumulated in the roots, and there are many studies on how plants respond to and tolerate high $\mathrm{NaCl}$ stress [2]. Under our study conditions, $20 \mathrm{mM}$ and higher concentrations of $\mathrm{NaCl}$ decreased plant growth, but surprisingly, $5 \mathrm{mM} \mathrm{NaCl}$ stimulated plant growth (Figures 1 and 7). At $5 \mathrm{mM} \mathrm{NaCl}$, the $\mathrm{Cl}^{-}$content in plants increased significantly, while the content of other anions, i.e., $\mathrm{NO}_{3}{ }^{-}, \mathrm{PO}_{4}{ }^{3-}$, and $\mathrm{SO}_{4}{ }^{2-}$, was not changed; however, 10 and $20 \mathrm{mM} \mathrm{NaCl}$ evidently inhibited these anions' accumulation in shoots (Figure 2). Moreover, $5 \mathrm{mM} \mathrm{NaCl}$ increased the levels of $\mathrm{C}, \mathrm{S}, \mathrm{Zn}$, and $\mathrm{Cu}$ in the shoots (Figures 3 and 4). We also observed a significant increase in Cys levels, indicating that low levels of $\mathrm{NaCl}$ stimulated the $\mathrm{S}$ assimilation process (Figure 5). Expression of salt stress-responsive genes significantly increased only in those plants grown in the presence of $20 \mathrm{mM} \mathrm{NaCl}$ (Figure 6). These results suggest that more than 10 or $20 \mathrm{mM}$ $\mathrm{NaCl}$ induces salt stress in plants; however, $5 \mathrm{mM} \mathrm{NaCl}$ does not induce such stress and, in fact, positively influences plant metabolism, resulting in plant growth.

The positive effects of low levels of $\mathrm{NaCl}$ seemed to be due to both $\mathrm{Na}^{+}$and $\mathrm{Cl}^{-}$, as both $\mathrm{KCl}$ and $\mathrm{NaNO}_{3}$ stimulated plant growth (Figure 7). However, the salt concentrations that increased plant growth differed for $\mathrm{KCl}$ and $\mathrm{NaNO}_{3} ; 10 \mathrm{mM} \mathrm{KCl}$ promoted plant growth but not $5 \mathrm{mM} \mathrm{KCl} ; 5 \mathrm{mM} \mathrm{NaNO}_{3}$ stimulated plant growth, whereas $10 \mathrm{mM} \mathrm{NaNO}_{3}$ inhibited plant growth. This suggests that the doses of $\mathrm{Na}^{+}$and $\mathrm{Cl}^{-}$capable of stimulating plant growth might be different, i.e., $10 \mathrm{mM}$ for $\mathrm{Cl}^{-}$and $5 \mathrm{mM}$ for $\mathrm{Na}^{+}$may promote plant growth; therefore, growth stimulation by $5 \mathrm{mM} \mathrm{NaCl}$ can be a result of combinatorial effects of both $\mathrm{Na}^{+}$and $\mathrm{Cl}^{-}$. In the MGRL medium used in this study [29] (Supplemental Tables S1 and S2), the initial concentration of $\mathrm{Na}^{+}$was $2.13 \mathrm{mM}$, and that of $\mathrm{Cl}^{-}$was $24.8 \mu \mathrm{M}$, comparable to those in Hoagland's medium containing 16 to $54 \mu \mathrm{M} \mathrm{Na}^{+}$and $50 \mathrm{M} \mathrm{M} \mathrm{Cl}^{-}$[30] (Supplemental Table S4).

Although the deficiency threshold for $\mathrm{Cl}^{-}$is accepted to be less than $100 \mu \mathrm{M}$, recent studies have demonstrated that some plants such as tobacco and tomato grew better with up to $5 \mathrm{mM} \mathrm{Cl}^{-}$[14], indicating that MGRL and Hoagland's media contain very low $\mathrm{Cl}^{-}$levels compared to those supporting maximum plant growth. The shoot $\mathrm{Cl}^{-}$ concentrations analyzed in this study were $2.1,53.9,94.3$, and $144.3 \mu \mathrm{g} /$ plant under 0,5 , 10 , and $20 \mathrm{mM} \mathrm{NaCl}$ application, respectively (Figure 2), which corresponded to 7.7, 183, 
421, and $609 \mathrm{mg} / \mathrm{g} \mathrm{DW}$, respectively. Considering that $\mathrm{Cl}^{-}$concentration in the shoots of non-halophyte plants ranges from 1 to $20 \mathrm{mg} / \mathrm{g}$ DW and that tobacco plants accumulate up to $50 \mathrm{mg} / \mathrm{g}$ DW when treated with $5 \mathrm{mM} \mathrm{Cl}^{-}[13,19,31]$, plant growth can be improved by increasing $\mathrm{Cl}^{-}$concentration in the medium up till $5 \mathrm{mM}$. Although $\mathrm{Na}^{+}$is not an essential element for plants, the application of a low amount of $\mathrm{Na}^{+}$stimulated plant growth [6]. Even if high salinity is known to decrease the root-to-shoot transport of $\mathrm{NO}_{3}{ }^{-}, \mathrm{PO}_{4}{ }^{3-}$, and $\mathrm{SO}_{4}{ }^{2-}$ by competition with $\mathrm{Cl}^{-}$(Figure 2) [13], plants in this study managed to maintain adequate levels of $\mathrm{Cl}^{-}$under $5 \mathrm{mM} \mathrm{NaCl}$, which resulted in adequate photosynthetic activity and osmotic conditions.

\subsection{How Does Low-Level $\mathrm{NaCl}$ Increase $\mathrm{C}$ and S Levels?}

Growth stimulation by $5 \mathrm{mM} \mathrm{NaCl}$ was accompanied by increased $\mathrm{C}$ and $\mathrm{S}$ levels (Figures 3 and 4). Since $\mathrm{Cl}^{-}$supports the light reaction of photosynthesis, this concentration of $\mathrm{Cl}^{-}$may stimulate photosynthesis and an eventual increase in the plant biomass (Figure 1) [13,14]. Consistently, the level of $\mathrm{Cu}$, another element involved in photosynthesis, increased, and those of other elements such as $\mathrm{Mg}$ and $\mathrm{Mn}$ tended to increase under the same conditions (Figure 4). Another possibility is that $\mathrm{NaCl}$ application may stimulate sucrose uptake from the medium. Although the $\mathrm{NaCl}$ concentration used in this study was different from the high levels of $\mathrm{NaCl}$ in other studies, salinity stress is known to increase the sugar content in leaves and stems and as well as the expression of some sugar transporters [32,33]. Moreover, $\mathrm{NaCl}$ is known to stimulate sucrose transport into vacuoles and sucrose accumulation in storage tissues, possibly by stimulating ATPase activity at the tonoplast membrane in beet [7]. As C levels increased in both shoots and roots, increased photosynthesis and increased sucrose uptake and transport to vacuoles could contribute to the increased levels of $\mathrm{C}$ in the presence of a low concentration of $\mathrm{NaCl}$.

Under salt stress, wherein the levels of S-containing metabolites such as Cys, GSH, and glucosinolates are increased $[25,34,35]$, the increase in $S$ metabolites is considered to improve the antioxidant capacity of plants. A high dose of $\mathrm{NaCl}(150-200 \mathrm{mM})$ increased the transcript levels and the activity of the enzymes involved in $\mathrm{S}$ assimilation, including ATP sulfurylase, APR, and O-acetylserine (thiol) lyase in Arabidopsis and Brassica crops [34-37]. In Brassica rapa, the expression of SULTR1s and sulfite reductase gene was decreased, but that of SULTR 4 was increased by 50 and $100 \mathrm{mM} \mathrm{NaCl}$ without affecting the total $\mathrm{S}$ level [38]. In our gene expression analysis, $\mathrm{NaCl}$ application did not influence the expression of $\mathrm{S}$ assimilatory genes, such as SULTR1;2, APR2, and APR3 (Figure 6). These results suggested that the increased $S$ level was not due to increased gene expression, although we did not analyze all S assimilatory genes. To maintain the cell's ion balance, cation influx into the cell is accompanied by that of inorganic anions such as $\mathrm{PO}_{4}{ }^{3-}, \mathrm{Cl}^{-}$, $\mathrm{NO}_{3}{ }^{-}$, and $\mathrm{SO}_{4}{ }^{2-}$ [7]. This may happen when $\mathrm{Na}^{+}$influx increases in roots, especially when $\mathrm{Cl}^{-}$is easily distributed from root to shoot, consistent with the increased tendency of $\mathrm{NO}_{3}{ }^{-}, \mathrm{PO}_{4}{ }^{3-}$, and $\mathrm{SO}_{4}{ }^{2-}$ and the increase of $\mathrm{N}$ and $\mathrm{P}$ in $5 \mathrm{mM} \mathrm{NaCl}$-treated roots (Figure 2). To explore this hypothesis, we need to investigate further how a low level of $\mathrm{NaCl}$ increases $\mathrm{S}$ assimilation.

\subsection{Possible Contribution of Increased $\mathrm{Zn}$ and $\mathrm{Cu}$ Levels to the Growth Stimulation Caused by a Low Level of $\mathrm{NaCl}$}

Unlike the responses to high salinity, the decrease in $\mathrm{Mg}, \mathrm{Ca}$, and $\mathrm{K}$ levels due to competitive transport with $\mathrm{Na}^{+}[4,5]$ was not observed in the presence of $5 \mathrm{mM} \mathrm{NaCl}$ (Figure 4) [38]. Instead, there was a slight increase in $\mathrm{Zn}$ and $\mathrm{Cu}$ in the shoots and of $\mathrm{Mg}$, $\mathrm{Ca}$, and $\mathrm{Cu}$ in the roots (Figure 4 ).

$\mathrm{Zn}$ and $\mathrm{Cu}$ are required for photochemical processes involved in photosynthesis [39-42]. As metal cofactors, $\mathrm{Zn}$ and $\mathrm{Cu}$ are the components of the copper-zinc superoxide dismutase $(\mathrm{Cu} / \mathrm{Zn}-\mathrm{SOD})$, which catalyzes the formation of $\mathrm{H}_{2} \mathrm{O}_{2}$ from superoxide radicals [42,43]. Overexpression of $\mathrm{Cu} / \mathrm{Zn}$-SOD significantly enhanced $\mathrm{NaCl}$ tolerance in Arabidopsis [44]. In addition to SOD, $\mathrm{Cu}$ acts as a cofactor of catalase and enzymes involved in the synthesis of phenolic compounds, which also function against oxidative damage in plants $[42,43]$. 
The plant growth stimulation caused by $5 \mathrm{mM} \mathrm{NaCl}$ (Figure 1) could be due to the increased photosynthetic activity supported by increased $\mathrm{Cu}$ and $\mathrm{Zn}$ contents in shoots and/or the increased antioxidant activity of SOD.

In this study, we found positive effects of low levels of $\mathrm{NaCl}$ on the growth of Arabidopsis. The elemental contents suggested that low levels of $\mathrm{NaCl}$ may provide a better ion balance among the elements, without disturbing cellular metabolism and the root-to-shoot distribution of other essential nutrients, and may even stimulate $C$ and $S$ assimilation, supporting plant growth and antioxidant activity. Although the precise mechanism has not been clarified, this finding can be implemented to provide better plant growth conditions.

\section{Materials and Methods}

\subsection{Plant Materials and Growth Conditions}

Arabidopsis thaliana plants, ecotype "Columbia" (Col-0), were used as the plant material. Plants were grown on mineral nutrient medium (Supplemental Tables S1 and S2) [29] containing $1 \%$ sucrose and $0.8 \%$ agarose at $22{ }^{\circ} \mathrm{C}$ under constant illumination $\left(40 \mu \mathrm{mol} \mathrm{m}{ }^{-2} \mathrm{~s}^{-1}\right)$. For $\mathrm{NaCl}$ treatment, plants were vertically grown on medium supplemented with $0,5,10$, 20, 40, or $60 \mathrm{mM} \mathrm{NaCl}$ (Sodium Chloride; Nacalai Tesque, Kyoto, Japan). Treatments with $\mathrm{KCl}$ (Potassium Chloride; Nacalai Tesque) and $\mathrm{NaNO}_{3}$ (Sodium Nitrate; Nacalai Tesque) were performed similarly.

\subsection{Measurement of Fresh and Dry Weights}

Eleven-day-old plants were separately harvested to obtain shoot and root tissues. After rinsing with distilled water, we counted the number of plants and determined their fresh weight $(\mathrm{FW})$.

\subsection{Anion Analysis}

Plant tissues were frozen in liquid nitrogen, homogenized with the Tissue Lyser MM300 (Retsch, Haan, Germany), and extracted with 5 volumes of ultrapure water. The resultant mixtures were centrifuged at $4{ }^{\circ} \mathrm{C}, 16,150 \times \mathrm{g}$ for $15 \mathrm{~min}$. The supernatant was used for anion analysis using ion chromatography (IC-2001, TOSOH, Tokyo, Japan) as described previously [45,46]. Anion mixture standard solution 1 (Wako Pure Chemicals, Tokyo, Japan) was used as a standard.

\subsection{Elemental Analysis}

Dried plant tissues were ground with the Tissue Lyser MM300 (Retsch, Germany) into fine powder. Carbon $(\mathrm{C})$ and nitrogen $(\mathrm{N})$ contents were analyzed in $1 \mathrm{mg}$ of powder using CHN Corder MT-6 (Yanaco Apparatus Development Laboratory, Tokyo, Japan). The content of sulfur (S) and other elements was analyzed using inductively coupled plasma-mass spectroscopy (ICP-MS; Agilent7700X, Agilent Technologies, Santa Clara, CA, USA). We digested $1 \mathrm{mg}$ of powder in $200 \mu \mathrm{L} \mathrm{HNO}$ at $95^{\circ} \mathrm{C}$ for $30 \mathrm{~min}$ and then at $115^{\circ} \mathrm{C}$ for about $90 \mathrm{~min}$. The digested samples were diluted to $1 \mathrm{~mL}$ with extra-pure water and filtered using $0.45 \mu \mathrm{m}$ filters (DISMIC-03CP, ADVANTEC, Tokyo, Japan). The filtered samples were diluted 10 times with a solution consisting of $0.1 \mathrm{M} \mathrm{HNO}_{3}$ and $10 \mu \mathrm{g} \mathrm{L}^{-1}$ gallium (KANTO CHEMICAL, Tokyo, Japan) as an internal standard before being subjected to ICP-MS. Quantification was performed using a standard curve obtained via serial dilutions of the standard solutions (KANTO CHEMICAL).

\subsection{Analysis of Cysteine (Cys) and Glutathione (GSH)}

The content of Cys and GSH was determined by an HPLC fluorescence detection system after labeling the thiol bases by monobromobimane, as described previously [47]. The labeled products were separated by HPLC using the TSKgel ODS-120T column $(150 \times 4.6 \mathrm{~mm}, \mathrm{TOSOH})$ and detected with a scanning fluorescence detector FP-920 (JASCO, Oklahoma, OK, USA), monitoring for fluorescence of thiol-bimane adducts at $478 \mathrm{~nm}$ under excitation at $390 \mathrm{~nm}$. Cys and GSH (Nacalai Tesque) were used as standards. 


\subsection{Gene Expression Analysis}

Total RNA was extracted from the shoot and root tissues using Sepasol-RNA I (Nacalai Tesque), and reverse transcription was conducted using the PrimeScript RT Reagent Kit with gDNA Eraser (Takara, Maebashi, Japan). Quantitative PCR was conducted using the KAPA SYBR FAST qPCR Master Mix $2 \times$ (Kapa Biosystems, Boston, MA, USA) and qTOWER3G touch (Analytik Jena AG, Germany). Relative mRNA abundance was determined using the $\Delta \Delta C \mathrm{Ct}$ method, and ubiquitin (UBQ2, accession no. J05508) was used as a constitutive internal control. Gene specific primers for quantitative PCR are listed in Supplemental Table S3 [48-50].

\subsection{Statistical Analysis}

Statistical analyses were performed by the Student's $t$-test using Microsoft Excel. The detected significant differences are indicated by asterisks $\left({ }^{*} 0.01 \leq p<0.05,{ }^{* *} 0.001 \leq p<0.01\right.$, *** $p<0.001)$.

Supplementary Materials: The following are available online at https:/ /www.mdpi.com/article/ 10.3390/plants10102138/s1, Table S1: Salt concentrations in the liquid culture medium, Table S2: Element concentrations in the liquid culture medium, Table S3: Primers used for quantitative RT-PCR, Table S4: Salt composition of Hoagland's medium.

Author Contributions: Conceptualization, A.M.-N.; methodology, N.M.-U. and A.M.-N.; formal analysis, A.S., N.M.-U. and A.M.-N.; data curation, L.H. and A.M.-N.; writing-original draft preparation, L.H. and A.M.-N.; writing-review and editing, A.M.-N., N.M.-U. and R.H.; supervision, A.M.-N. and R.H.; funding acquisition, A.M.-N. All authors have read and agreed to the published version of the manuscript.

Funding: This research was funded by JSPS KAKENHI Grant Numbers JP24380040, JP17H03785, JP20H05511, the Salt Science Research Foundation (Grant Number 1120), the Joint Usage/Research Center, Institute of Plant Science and Resources, Okayama University (Grant Number R218, R311), and Initiative for Realizing Diversity in the Research Environment (for A.M.N.).

Institutional Review Board Statement: Not applicable.

Informed Consent Statement: Not applicable.

Data Availability Statement: All data were provided within the article and Supplemental files.

Acknowledgments: We thank Yukiko Okuo, Tomoko Yoshida-Ono and Sanae Rikiishi for their technical support. C and N contents were analyzed by the Service Center of the Elementary Analysis of Organic Compounds, Faculty of Science, Kyushu University. The ICP-MS analysis was performed at the Center of Advanced Instrumental Analysis, Kyushu University, and at the Okayama University Institute of Plant Science and Resources. Plant growth and seed harvesting were done at the Biotron Application Center, Kyushu University.

Conflicts of Interest: The authors declare no conflict of interest. The funders had no role in the design of the study; in the collection, analyses, or interpretation of data; in the writing of the manuscript, or in the decision to publish the results.

\section{References}

1. Flowers, T.; Yeo, A. Breeding for salinity resistance in crop plants: Where Next? Aust. J. Plant Physiol. 1995, 22, 875-884. [CrossRef]

2. Zelm, E.V.; Zhang, Y.; Testerink, C. Salt tolerance mechanisms of plants. Annu. Rev. Plant Biol. 2020, 71, 403-433. [CrossRef] [PubMed]

3. Purty, R.S.; Kumar, G.; Singla-Pareek, S.L.; Pareek, A. Towards salinity tolerance in Brassica: An overview. Physiol. Mol. Biol. Plants 2008, 14, 39-49. [CrossRef] [PubMed]

4. Keisham, M.; Mukherjee, S.; Bhatla, S.C. Mechanisms of sodium transport in plants-progresses and challenges. Int. J. Mol. Sci. 2018, 19, 647. [CrossRef] [PubMed]

5. Yamaguchi, T.; Hamamoto, S.; Uozumi, N. Sodium transport system in plant cells. Front. Plant Sci. 2013, 4, 410-416. [CrossRef]

6. Broadley, M.R.; White, P.J. Some elements are more equal than others: Soil-to-plant transfer of radiocaesium and radiostrontium, revisited. Plant Soil 2012, 355, 23-27. [CrossRef] 
7. Subbarao, G.V.; Ito, O.; Berry, W.L.; Wheeler, R.M. Sodium-A functional plant nutrient. CRC Crit. Rev. Plant. Sci. 2003, 22, 391-416.

8. Furumoto, T.; Yamaguchi, T.; Ohshima-Ichie, Y.; Nakamura, M.; Tsuchida-Iwata, Y.; Shimamura, M.; Ohnishi, J.; Hata, S.; Gowik, U.; Westhoff, P. A plastidial sodium-dependent pyruvate transporter. Nature 2011, 476, 472-475. [CrossRef]

9. Flowers, T.J.; Läuchli, A. Sodium versus potassium: Substitution and compartmentation. In Encyclopedia of Plant Physiology; LaĚuchli, A., Bieleski, R.L., Eds.; Springer: Berlin, Germany, 1983; Volume 15B, pp. 651-681.

10. Blumwald, E. Sodium transport and salt tolerance in plants. Curr. Opin. Cell Biol. 2000, 12, 431-434. [CrossRef]

11. Ebrahimi, R.; Bhatla, S.C. Effect of sodium chloride levels on growth, water status, uptake, transport, and accumulation pattern of sodium and chloride ions in young sunflower plants. Commun. Soil Sci. Plant Anal. 2011, 42, 815-831. [CrossRef]

12. Lee, M.K.; van Iersel, M.W. Sodium Chloride Effects on Growth, Morphology, and Physiology of Chrysanthemum (Chrysanthemum $\times$ morifolium). HortScience 2008, 43, 1888-1891. [CrossRef]

13. Geilfus, C.M. Chloride: From nutrient to toxicant. Plant Cell Physiol. 2018, 59, 877-886. [CrossRef] [PubMed]

14. Colmenero-Flores, J.M.; Franco-Navarro, J.D.; Cubero-Font, P.; Peinado-Torrubia, P.; Rosales, M.A. Chloride as a beneficial macronutrient in higher plants: New roles and regulation. Int. J. Mol. Sci. 2019, 20, 4686. [CrossRef]

15. Tsunekawa, K.; Shijuku, T.; Hayashimoto, M.; Kojima, Y.; Onai, K.; Morishita, M.; Ishiura, M.; Kuroda, T.; Nakamura, T.; Kobayashi, H. Identification and characterization of the $\mathrm{Na}^{+} / \mathrm{H}^{+}$antiporter nhaS3 from the thylakoid membrane of Synechocystis sp. PCC 6803. J. Biol. Chem. 2009, 284, 16513-16521. [CrossRef] [PubMed]

16. Saito, S.; Uozumi, N. Guard cell membrane anion transport systems and their regulatory components. An elaborate mechanism controlling stress-induced stomatal closure. Plants 2019, 8, 9. [CrossRef]

17. Xu, G.; Magen, H.; Tarchitzky, J.; Kafkafi, U. Advances in chloride nutrition of plants. Adv. Agron. 2000, 68, 97-110.

18. Chen, W.; He, Z.L.; Yang, X.E.; Mishra, S.; Stoffella, P.J. Chlorine nutrition of higher plants: Progress and perspectives. Plant Nutr. 2010, 33, 943-952. [CrossRef]

19. Franco-Navarro, J.D.; Javier, B.; Rosales, M.A.; Paloma, C.F.; Manuel, T.; Colmenero-Flores, J.M. Chloride regulates leaf cell size and water relations in tobacco plants. J. Exp. Bot. 2015, 67, 873-891. [CrossRef]

20. Franco-Navarro, J.D.; Miguel, A.R.; Paloma, C.F.; Purificación, C.; Rosario, Á.; Antonio, D.E.; Colmenero-Flores, J.M. Chloride as a macronutrient increases water-use efficiency by anatomically driven reduced stomatal conductance and increased mesophyll diffusion to $\mathrm{CO}_{2}$. Plant J. 2019, 99, 815-831.

21. Takahashi, H.; Kopriva, S.; Giordano, M.; Saito, K.; Hell, R. Sulfur assimilation in photosynthetic organisms: Molecular functions and regulations of transporters and assimilatory enzymes. Annu. Rev. Plant Biol. 2011, 62, 157-184. [CrossRef]

22. Maruyama-Nakashita, A. Metabolic changes sustain the plant life in low-sulfur environments. Curr. Opin. Cell Biol. 2017, 39, 144-151. [CrossRef]

23. Yamaguchi, C.; Ohkama-Ohtsu, N.; Shinano, T.; Maruyama-Nakashita, A. Plants prioritize phytochelatin synthesis during cadmium exposure even under reduced sulfate uptake caused by the disruption of SULTR1;2. Plant Signal. Behav. 2017, 12, e1325053. [CrossRef]

24. Nazar, R.; Iqbal, N.; Masood, A.; Syeed, S.; Khan, N.A. Understanding the significance of sulfur in improving salinity tolerance in plants. Environ. Exp. Bot. 2011, 70, 80-87. [CrossRef]

25. Khan, N.; Khan, M.I.R.; Asgher, M.; Mehar, F. Salinity tolerance in plants: Revisiting the role of sulfur metabolites. J. Plant Biochem. Physiol. 2014, 2, 120-128.

26. Astolfi, S.; Zuchi, S. Adequate S supply protect sbarley plants from adverse effects of salinity stress by increasing thiol contents. Acta Physiol. Plant. 2013, 35, 175-181. [CrossRef]

27. Bae, M.J.; Kim, Y.S.; Kim, I.S.; Choe, Y.H.; Lee, E.J.; Kim, Y.H.; Park, H.M.; Yoon, H.S. Transgenic rice overexpressing the Brassica juncea gamma-glutamylcysteine synthetase gene enhances tolerance to abiotic stress and improves grain yield under paddy field conditions. Mol. Breeding 2013, 31, 931-945. [CrossRef]

28. Broadly, M.; Brown, P.; Cakmak, I.; Rengel, Z.; Zhao, F. Functions of nutrients micronutrients. In Mineral Nutrition of Higher Plants, 3rd ed.; Marschner, P., Ed.; Academic Press: Waltham, MA, USA, 2011; pp. 191-243.

29. Fujiwara, T.; Hirai, M.Y.; Chino, M.; Naito, S. Effects of sulfur nutrition on expression of the soybean seed storage protein genes in transgenic petunia. Plant Physiol. 1992, 99, 263-268. [CrossRef]

30. Vijayaraghavareddy, P.; Adhinarayanreddy, V.; Vemanna, R.S.; Sreeman, S.; Makarla, U. Quantification of membrane damage/Cell death using evan's blue staining technique. Bio Protoc. 2017, 16, e2519.

31. Marschner, P.; Crowley, D.; Rengel, Z. Rhizosphere interactions between microorganisms and plants govern iron and phosphorus acquisition along the root axis—-model and research methods. Soil Biol. Biochem. 2011, 43, 883-894. [CrossRef]

32. Hartmann, L.; Pedrotti, L.; Weiste, C.; Fekete, A.; Schierstaedt, J.; Göttler, J.; Kempa, S.; Krischke, M.; Dietrich, K.; Mueller, M.J.; et al. Crosstalk between two bZIP signaling pathways orchestrates salt-induced metabolic reprogramming in Arabidopsis roots. Plant Cell 2015, 27, 2244-2260. [CrossRef]

33. Sellami, S.; Hir, R.L.; Thorpe, M.R.; Vilaine, F.; Wolff, N.; Brini, F.; Dinant, S. Salinity effects on sugar homeostasis and vascular anatomy in the Stem of the Arabidopsis thaliana inflorescence. Int. J. Mol. Sci. 2019, 20, 3167. [CrossRef]

34. Ruiz, J.M.; Blumwald, E. Salinity-induced glutathione synthesis in Brassica napus. Planta 2002, 214, 965-969. [CrossRef]

35. Koprivova, A.; North, K.A.; Kopriva, S. Complex signaling network in regulation of adenosine $5^{\prime}$-phosphosulfate reductase by salt stress in Arabidopsis roots. Plant Physiol. 2008, 146, 1408-1420. [CrossRef] 
36. Romero, L.C.; Domínguez-Solís, J.R.; Gutiérrez-Alcalá, G.; Gotor, C. Salt regulation of O-acetylserine (thiol) lyase in Arabidopsis thaliana and increased tolerance in yeast. Plant Physiol. Biochem. 2001, 39, 643-647. [CrossRef]

37. Sharma, R.; Mishra, M.; Gupta, B.; Parsania, C.; Singla-Pareek, S.L.; Pareek, A. De novo assembly and characterization of stress transcriptome in a salinity-tolerant variety CS52 of Brassica juncea. PLoS ONE 2015, 10, e0126783. [CrossRef]

38. Reich, M.; Aghajanzadeh, T.; Helm, J.; Parmar, S.; Hawkesford, M.J.; De Kok, L.J. Chloride and sulfate salinity differently affect biomass, mineral nutrient composition and expression of sulfate transport and assimilation genes in Brassica rapa. Plant Soil 2017, 411, 319-322. [CrossRef] [PubMed]

39. Cakmak, I. Possible role of zinc in protecting plant cells from damage by reactive oxygen species. New Phytol. 2000, 146, 185-205. [CrossRef]

40. Hajiboland, R.; Amirazad, F. Growth, photosynthesis, and antioxidant defense system in Zn-deficient red cabbage plants. Plant Soil Environ. 2010, 56, 209-217. [CrossRef]

41. Chen, W.; Yang, X.; He, Z.; Feng, Y.; Hu, F. Differential changes in photosynthetic capacity, 77K chlorophyll fluorescence and chloroplast ultrastructure between Zn-efficienct and Zninefficient rice genotypes (Oryza sativa L.) under low Zn stress. Plant Physiol. 2007, 132, 89-101.

42. Mehrizi, M.H.; Shariatmadari, H.; Khoshgoftarmanesh, A.H.; Dehghani, F. Copper effects on growth, lipid peroxidation, and total phenolic content of rosemary leaves under salinity stress. J. Agric. Sci. Technol. 2011, 14, 205-212.

43. Fridovich, I. Superoxide radical and superoxide dismutases. Annu. Rev. Biochem. 1995, 64, 97-112. [CrossRef]

44. Shafi, A.; Mir, M.A.; Zahoor, I. Effect of salinity stress on germination, tolerance, and antioxidant response in Arabidopsis thaliana overexpressing $\mathrm{Cu} / \mathrm{Zn}-\mathrm{SOD}$. Int. J. Life Sci. Res. 2019, 5, 69-78.

45. Maruyama-Nakashita, A.; Watanabe-Takahashi, A.; Inoue, E.; Yamaya, T.; Saito, K.; Takahashi, H. Sulfur-Responsive elements in the $3^{\prime}$-nontranscribed intergenic region are essential for the induction of SULFATE TRANSPORTER 2;1 gene expression in Arabidopsis roots under sulfur deficiency. Plant Cell 2015, 27, 1279-1296. [CrossRef] [PubMed]

46. Kimura, Y.; Ushiwatari, T.; Suyama, A.; Tominaga-Wada, R.; Wada, T.; Maruyama-Nakashita, A. Contribution of root hair development to sulfate uptake in Arabidopsis. Plants 2019, 8, 106. [CrossRef]

47. Zhang, L.; Ryota, K.; Tomomi, M.I.; Allahham, A.; Kim, S.J.; Maruyama-Nakashita, A. Sulfur Deficiency-induced glucosinolate catabolism attributed to two $\beta$-Glucosidases, BGLU28 and BGLU30, is required for plant growth maintenance under sulfur deficiency. Plant Cell Physiol. 2020, 61, 803-813. [CrossRef] [PubMed]

48. Bassil, E.; Tajima, H.; Liang, Y.C.; Ohto, M.A.; Ushijima, K.; Nakano, R.; Esumi, T.; Coku, A.; Belmonte, M.; Blumwald, E. Arabidopsis $\mathrm{Na}^{+} / \mathrm{H}^{+}$antiporters NHX1 and NHX2 control vacuolar $\mathrm{pH}$, and reproduction. Plant Cell 2011, 23, 3482-3497. [CrossRef]

49. Qiu, J.; Henderson, S.W.; Mark, T.; Roy, S.J.; Mathew, G. SLAH1, a homologue of the slow type anion channel SLAC1, modulates shoot $\mathrm{Cl}$ accumulation and salt tolerance in Arabidopsis thaliana. J. Exp. Bot. 2016, 67, 4495-4505. [CrossRef]

50. Maruyama-Nakashita, A.; Hirai, M.Y.; Funada, S.; Fueki, S. Exogenous application of 5-aminolevulinic acid increases the transcript levels of sulfur transport and assimilatory genes, sulfate uptake, and cysteine and glutathione contents in Arabidopsis thaliana. Soil Sci. Plant Nutr. 2010, 56, 281-288. [CrossRef] 